\title{
INTERCROPPING SQUASH WITH MAIZE UNDER VARYING PLANTING SYSTEM
}

\author{
J.A. Chowdhury ${ }^{1}$, S.S. Kakon ${ }^{1}$, A.A. Begum ${ }^{1}$ and M.A.K. Mian ${ }^{2}$ \\ ${ }^{1}$ Senior Scientific Officer, Agronomy Division, Bangladesh Agricultural Research Institute, Gazipur-1701 \\ ${ }^{2}$ Principal Scientific Officer, Agronomy Division, Bangladesh Agricultural Research Institute, Gazipur- \\ 1701 \\ "Corresponding Author, E-mail: jasminedaisy.bari@gmail.com
}

(Received: 7 November 2017, Accepted: 9 April 2019)

\begin{abstract}
The experiment was conducted at the research field of Agronomy Division, Bangladesh Agricultural Research Institute (BARI), Joydebpur, Gazipur during rabi seasons of 2014-15 and 2015-16 to find out the suitable planting arrangement of squash (var. Bulam House) with maize (var. BARI Hybrid maize-9) as intercropping for higher productivity and economic return. Seven treatment combinations viz. maize normal plating $(75 \mathrm{~cm} \times 25 \mathrm{~cm})$, maize normal plating $(75 \mathrm{~cm} \times 25 \mathrm{~cm})(100 \%)+1$ row squash (Plant to Plant $80 \mathrm{~cm})(116 \%)$, maize paired row $(37.5 \mathrm{~cm}$ $\times 150 \mathrm{~cm} \times 37.5 \mathrm{~cm})(100 \%)+1$ row squash (Plant to Plant $80 \mathrm{~cm})$ $(50 \%)$, maize paired row $(100 \%)+1$ row squash (Plant to Plant 100 $\mathrm{cm})(40 \%)$, maize paired row $(100 \%)+2$ rows squash (Plant to Plant $80 \mathrm{~cm})(100 \%)$, maize paired row $(100 \%)+2$ rows squash (80\%) (Plant to Plant $100 \mathrm{~cm})$ and sole Squash $(100 \mathrm{~cm} \mathrm{Y} 80 \mathrm{~cm})$ were tested. Results showed that the highest grain yield of maize $\left(9.47 \mathrm{t} \mathrm{ha}{ }^{-1}\right.$ in 2014-15 and 9.24 t ha ${ }^{-1}$ in 2015-16) and squash yield (28.19 $\mathrm{t} \mathrm{ha}^{-1}$ in 2014-15 and 25.02 $\mathrm{t} \mathrm{ha}^{-1}$ in 2015-16) were recorded in sole crop, respectively. Maximum mean maize equivalent yield $\left(19.39 \mathrm{t} \mathrm{ha}^{-1}\right)$ was recorded in maize paired row (100\%) + 2 row squash (Plant to Plant 80 $\mathrm{cm})(100 \%)$ combination in both the year. The highest gross return (Tk. 2,93,850 ha-1), gross margin (Tk. 1,92,450 ha $\mathrm{ha}^{-1}$ ) and BCR (2.95) were also obtained from the same combinations. Two years' results revealed that maize paired row +2 rows squash (Plant to Plant $80 \mathrm{~cm}$ ) combination could be suitable for higher productivity and economic return.
\end{abstract}

\section{Introduction}

Bangladesh is a small country but food demand is higher due to high rate of plant population. In order to produce more food within a limited area, one of the most important options is to increase the cropping intensity through intercropping which was higher productivity per unit area of land (Ahmed et al., 2013). Intercropping is one of the cropping strategies that have been recognized to improve the food security situation and higher incomes for the farmers (Mahfuza, 2012). It also helps to reduce weed populations, insect and pest infestation and risk of complete crop failure (Islam et al., 2013). Intercropping is a traditional practice in Bangladesh but the important determinants in intercropping systems are the judicious choice of compatible crops with minimum inter-specific competition, suitable planting system or proportion of component crops (Islam et al., 2004). Production of vegetables grown under intercropping depends on the component of crops selected as well as row arrangements (Lewis et al., 2003). Maize is an important cereal crop and squash is also very promising vegetable. There is a scope to grow maize and squash as intercrop. In maize-squash intercropping system generally maximum yield of maize and bonus 
yield of squash is desired. Spatial arrangement, like sowing of maize in paired may allow more light to underneath squash for its better growth and productivity (Shivay et al, 1999). Moreover, higher density of squash may be accommodated in wider space in between paired rows of maize (Islam, 2002). However, information relating spatial arrangement of maize in accordance with accommodation of different densities of squash intercropping system is scarce under Bangladesh condition. So, this experiment was undertaken to find out suitable planting arrangement of squash intercrop with maize for getting higher productivity and economic return.

\section{Materials and Methods}

The experiment was conducted at the research field of Agronomy Division, Bangladesh Agricultural Research Institute (BARI), Joydebpur, Gazipur during rabi seasons of 2014-15 and 2015-2016. The treatments were $\mathrm{T}_{1}$ : Maize normal plating $(75 \mathrm{~cm} \times 25 \mathrm{~cm}), \mathrm{T}_{2}$ : Maize normal plating $(100 \%)+1$ row squash (Plant to Plant $80 \mathrm{~cm})(116 \%), \mathrm{T}_{3}$ : Maize paired row $37.5 \mathrm{~cm} / 150 \mathrm{~cm} / 37.5$ $\mathrm{cm}(100 \%)+1$ row squash (Plant to Plant $80 \mathrm{~cm})(50 \%), \mathrm{T}_{4}$ : Maize paired row $(100 \%)+1$ row squash (Plant to Plant $100 \mathrm{~cm})(40 \%), \mathrm{T}_{5}$ : Maize paired row $(100 \%)+2$ rows squash (Plant to Plant $80 \mathrm{~cm})(100 \%), \mathrm{T}_{6}$ : Maize paired row $(100 \%)+2$ rows squash $(80 \%)$ and $\mathrm{T}_{7}$ : Sole Squash $(100 \mathrm{~cm} \times 80 \mathrm{~cm})$. The experiment was laid out in randomized complete block (RCB) design with 3 replications. The unit plot size was $4 \mathrm{~m} \times 4.5 \mathrm{~m}$. Maize var. BARI Hybrid maize-9 and squash (var. Bulam House) were used as test crop. Seeds of both crops were sown on 24 November, 2014 and 20 November, 2015. Fertilizers were applied at the rate of 250-120-120-40-5 kg ha-1 NPKSZn $+10 \mathrm{t}$ cowdung $\mathrm{ha}^{-1}$ for sole maize and intercrop treatments. Half $\mathrm{N}$ and all other fertilizer was applied as basal. Remaining $\mathrm{N}$ was applied at 15 and 35 days after sowing (DAS) in two equal splits. Additional $40 \mathrm{~kg} \mathrm{ha}^{-1} \mathrm{~N}$ was applied in intercropping treatment. In sole squash the crop was fertilized at the rate of 80-35-75-20-4-2 $\mathrm{kg} \mathrm{ha}{ }^{-1} \mathrm{NPKSZnB}+20 \mathrm{t}$ cowdung ha ${ }^{-1}$. Chemical fertilizers were used in the form of urea, triple super phosphate, muriate of potash, gypsum, zinc sulphate and boric acid. Intercultural operations like watering, weeding and pest control were done as and when required. Squash was harvested during 21 January to 24 February in 2015 and 20 January to 16 February in 2016. Maize was harvested on 22 April in 2015 and 25 April in 2016. Yield components of both crops were taken from randomly selected 5 plants from each plot. Yields of both the crops were taken from whole plot. Land equivalent ratio (LER) values were computed from the yield data of the crops according to Willey (1985). Collected data of twocrops were analyzed statistically and the means were adjudged using Least Significant Difference (LSD) test at 5\% level. Benefit-cost analysis was also done.

Maize equivalent yields were computed by converting yield of intercrops on the basis of prevailing market price of the individuals by using the formula of Bandyopadhaya (1984).

Maize equivalent yield (MEY) $\left(\mathrm{kg} \mathrm{ha}^{-1}\right)=\operatorname{Yim}+\frac{\mathrm{Yis} . \mathrm{P} s .}{\mathrm{P} \mathrm{m}}$

Where, Yim = Maize yield $\left(\mathrm{kg} \mathrm{ha}^{-1}\right)$ in intercropping.

Yis. = Squash yield $\left(\mathrm{kg} \mathrm{ha}^{-1}\right)$ in intercropping

$\mathrm{Pm}=$ Price of Maize $\left(\mathrm{Tk} \mathrm{kg}^{-1}\right)$

Ps. = Price of Squash $\left(\mathrm{Tk} \mathrm{kg}^{-1}\right)$ 


\section{Results and Discussion}

\section{Performance of maize}

Single cob weight, 1000- grain weight and grain yield ha ${ }^{-1}$ of maize were significantly affected when grown in association with squash under different treatment combinations (Table -1). Higher single cob weight $(251.27 \mathrm{gm}$ in 2014-15 and 258.2 gm in 2015-16) was observed in sole maize followed by MPR + 1 row squash (40 \%) and the lowest (181.27 gm in 2014-15 and $208.7 \mathrm{gm}$ in 2015-16) in MNP (100\%) + 1 row squash (116\%) treatment combination. Similar trend was observed in 1000-seed weight in both years. The value of these parameters was reduced with increasing in squash population. The lower value of those parameters might be due to increased plant population as well as more inter specific competition. The highest grain yield $\left(9.47 \mathrm{t} \mathrm{ha}^{-1}\right.$ in 2014-15 and 9.24 $\mathrm{t} \mathrm{ha}^{-1}$ in 2015-16) was obtained from sole maize might be due to higher single cob weight and 1000-grain weight. Similar results were also reported by Uddin et al., 2009. Among the intercropped combinations, the maximum grain yield (9.01 t ha $\mathrm{h}^{-1}$ in 2014-15 and $8.3 \mathrm{t} \mathrm{ha}^{-1} \mathrm{gm}$ in 2015-16) of maize was recorded when it was grown as paired row (100\%) +1 row squash (40\%) due to less inter specific competition. The lowest grain yield $\left(7.27 \mathrm{t} \mathrm{ha}{ }^{-1}\right.$ in 2014-15 and 7.5 t ha ${ }^{-1}$ in 2015-16) was obtained from maize normal planting $(100 \%)+1$ row squash (Plant to Plant $80 \mathrm{~cm})(116 \%)$ due to increased plant population of squash that resulted lower single cob weight and 1000 grain weight.

Table 1. Grain yield and yield components of maize in maize squash intercropping system during 2014-15 and 2015-16

\begin{tabular}{|c|c|c|c|c|c|c|}
\hline \multirow[t]{2}{*}{ Treatments } & \multicolumn{2}{|c|}{$\begin{array}{l}\text { Single cob wt } \\
\text { (gm) }\end{array}$} & \multicolumn{2}{|c|}{$\begin{array}{l}1000-\text { grain wt } \\
\text { (gm) }\end{array}$} & \multicolumn{2}{|c|}{$\begin{array}{l}\text { Grain yield } \\
(\mathrm{t} \mathrm{ha})\end{array}$} \\
\hline & $\begin{array}{c}2014- \\
15\end{array}$ & $\begin{array}{l}2015- \\
16\end{array}$ & $\begin{array}{c}2014- \\
15\end{array}$ & $\begin{array}{l}2015- \\
16\end{array}$ & $\begin{array}{c}2014- \\
15\end{array}$ & $\begin{array}{l}2015- \\
16\end{array}$ \\
\hline $\begin{array}{l}\text { Maize normal planting } \\
(75 \mathrm{~cm} \times 25 \mathrm{~cm})\end{array}$ & 251.27 & 258.2 & 329.55 & 352.2 & 9.47 & 9.24 \\
\hline $\begin{array}{l}\text { Maize normal planting }(100 \%)+ \\
1 \text { row squash (Pl. to } \mathrm{Pl} .80 \\
\mathrm{~cm}(116 \%)\end{array}$ & 181.27 & 208.7 & 263.56 & 310.53 & 7.27 & 7.5 \\
\hline $\begin{array}{l}\text { Maize paired row }(100 \%)+1 \\
\text { row squash }(\mathrm{Pl} \text {. to } \mathrm{Pl} .80 \mathrm{~cm}) \\
(50 \%)\end{array}$ & 226.8 & 248.3 & 300.67 & 342.6 & 8.82 & 8.02 \\
\hline $\begin{array}{l}\text { Maize paired row }(100 \%)+1 \\
\text { row squash }(\mathrm{Pl} \text {. to } \mathrm{Pl} .1 \mathrm{~m}) \\
(40 \%)\end{array}$ & 236.67 & 252.88 & 305.46 & 342.8 & 9.01 & 8.3 \\
\hline $\begin{array}{l}\text { Maize paired row }(100 \%)+2 \\
\text { rows squash (Pl. to } \mathrm{Pl} .80 \mathrm{~cm}) \\
(100 \%)\end{array}$ & 186.4 & 213.65 & 284.1 & 312.4 & 8.00 & 7.67 \\
\hline $\begin{array}{l}\text { Maize paired row }(100 \%)+2 \\
\text { rows squash }(80 \%)\end{array}$ & 206.2 & 235.75 & 303.37 & 332.6 & 8.38 & 8.2 \\
\hline Sole Squash $(1 \mathrm{~m} \times 80 \mathrm{~cm})$ & - & - & - & - & - & - \\
\hline $\begin{array}{l}\operatorname{LSD}_{(0.05)} \\
\mathrm{CV}(\%)\end{array}$ & $\begin{array}{l}59.13 \\
16.09\end{array}$ & $\begin{array}{c}24.47 \\
5.69\end{array}$ & $\begin{array}{l}44.6 \\
8.12\end{array}$ & $\begin{array}{c}25.32 \\
4.2\end{array}$ & $\begin{array}{c}2.14 \\
13.89\end{array}$ & $\begin{array}{l}0.89 \\
5.96\end{array}$ \\
\hline
\end{tabular}

\section{Performance of squash:}

Fruit number plant ${ }^{-1}$, fruit weight plant $^{-1}$, and fruit yield of squash were significantly influenced under different intercropping system in both the years (Table 2). The highest fruit plant ${ }^{-1}$ (3.66 in 2014-15 and 3.16 in 2015-16) and weight of fruit plant $^{-1}(3.92 \mathrm{~kg}$ in $2014-15$ and $3.43 \mathrm{~kg}$ in 2015-16) were recorded from sole squash. In case of intercropping system, the highest number 
of fruit plant ${ }^{-1}$ (2.88 in 2014-15 and 2.63 in 2015-16) and weight of fruit plant 1 (3.21 kg in 2014-15 and $2.96 \mathrm{~kg}$ in 2015-16) were obtained when $40 \%$ squash was sown and the lowest values when $116 \%$ squash with maize. It might be due to competition for resources. Single fruit weight was significantly affected by intercropping system in 2015-16 but not in 2014-15. The highest single fruit weight was found in sole plot. Among intercropping system the highest fruit weight was obtained from MPR+ 1 row squash (40\%) combination. Sole squash showed highest fruit weight /plant. The highest fruit yield $\left(28.19 \mathrm{t} \mathrm{ha}^{-1}\right.$ in 201415 and $25.02 \mathrm{t} \mathrm{ha}^{-1}$ in 2015-16) was found in sole squash. There was trend to decrease fruit yield in both normal and paired row situation as intercrop. The lowest yield (11.73 $\mathrm{t} \mathrm{ha}^{-1}$ in 2014-15 and $8.26 \mathrm{t} \mathrm{ha}^{-1}$ in 2015-16) was obtained when $40 \%$ squash was sown with maize. Significant yield differences in different intercropping systems mainly attributed to the differences in plant population. Increasing the density of squash plants significantly increased the yield of intercropped squash compared to that obtained from intercropped with low density of squash populations. In intercropping situation the highest squash yield (19.39 $\mathrm{t} \mathrm{ha}^{-1}$ in 2014-15 and $14.76 \mathrm{t} \mathrm{ha}^{-1}$ in 2015-16) was obtained in Maize paired row $(100 \%)+2$ rows squash (Plant to Plant $80 \mathrm{~cm})(100 \%)$ treatment.

Table 2. Fruit yield and yield components of squash in maize squash intercropping system during 2014-15 and 2015- 16

\begin{tabular}{|c|c|c|c|c|c|c|c|c|}
\hline \multirow[t]{2}{*}{ Treatments } & \multicolumn{2}{|c|}{$\begin{array}{l}\text { Fruit plant }{ }^{-1} \\
\text { (no.) }\end{array}$} & \multicolumn{2}{|c|}{$\begin{array}{c}\text { Single fruit wt. } \\
(\mathrm{kg})\end{array}$} & \multicolumn{2}{|c|}{$\begin{array}{l}\text { Fruit wt. } \\
\text { plant }^{-1}(\mathrm{~kg})\end{array}$} & \multicolumn{2}{|c|}{$\begin{array}{l}\text { Fruit yield } \\
(\mathrm{t} \mathrm{ha-1)}\end{array}$} \\
\hline & $\begin{array}{l}2014- \\
15\end{array}$ & $\begin{array}{l}2015- \\
16\end{array}$ & $\begin{array}{l}2014- \\
15\end{array}$ & $\begin{array}{l}2015- \\
16\end{array}$ & $\begin{array}{c}2014- \\
15\end{array}$ & $\begin{array}{c}2015- \\
16\end{array}$ & $\begin{array}{l}2014- \\
15\end{array}$ & $\begin{array}{l}2015- \\
16\end{array}$ \\
\hline $\begin{array}{l}\text { Maize norm } \\
\mathrm{cm} \times 25 \mathrm{cr}\end{array}$ & & & & & & & 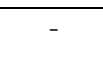 & - \\
\hline $\begin{array}{l}\text { Maize normal planting } \\
(100 \%)+1 \text { row squash } \\
(\mathrm{Pl} \text { to } \mathrm{Pl} .80 \mathrm{~cm})(116 \%)\end{array}$ & 2.22 & 2.13 & 1.12 & 1.17 & 2.17 & 1.91 & 15.17 & 10.35 \\
\hline $\begin{array}{l}\text { Maize paired row }(100 \%)+ \\
1 \text { row squash }(\mathrm{Pl} \text {. to } \mathrm{Pl} . \\
80 \mathrm{~cm})(50 \%)\end{array}$ & 2.44 & 2.4 & 1.16 & 1.34 & 2.67 & 2.73 & 13.46 & 9.68 \\
\hline $\begin{array}{l}\text { Maize paired row }(100 \%)+ \\
1 \text { row squash }(\mathrm{Pl} \text {. to } \mathrm{Pl} .1 \\
\mathrm{m})(40 \%)\end{array}$ & 2.88 & 2.63 & 1.2 & 1.44 & 3.21 & 2.96 & 11.73 & 8.26 \\
\hline $\begin{array}{l}\text { Maize paired row }(100 \%)+ \\
2 \text { rows squash }(\mathrm{Pl} \text {. to } \mathrm{Pl} \text {. } \\
80 \mathrm{~cm})(100 \%)\end{array}$ & 2.3 & 2.3 & 1.1 & 1.24 & 2.24 & 2.13 & 19.39 & 14.76 \\
\hline $\begin{array}{l}\text { Maize paired row }(100 \%)+ \\
2 \text { rows squash }(80 \%)\end{array}$ & 2.33 & 2.36 & 1.14 & 1.26 & 2.3 & 2.53 & 17.61 & 10.95 \\
\hline $\begin{array}{l}\text { Sole Squash (1 } \mathrm{m} \times 80 \\
\mathrm{~cm})\end{array}$ & 3.66 & 3.16 & 1.26 & 1.70 & 3.92 & 3.43 & 28.19 & 25.02 \\
\hline $\operatorname{LSD}_{(0.05)}$ & 0.49 & 0.37 & NS & 0.16 & 0.68 & 0.68 & 5.09 & 2.00 \\
\hline CV $(\%)$ & 10.30 & 9.09 & 5.87 & 6.24 & 13.58 & 0.315 & 16.21 & 8.61 \\
\hline
\end{tabular}

$\mathrm{NS}=$ Not significant; $\mathrm{Pl}=$ Plant

\section{Intercrop efficiency}

Maize equivalent yield (MEY), land equivalent ratio (LER) and benefit cost analysis of maize squash intercropping are presented in Table 3. Maize equivalent yield was influenced by different intercropping systems. It was noted that all the intercropping systems gave higher maize equivalent yields than that of sole maize yield. Maize equivalent yields (4.97-19.39 $\mathrm{t} \mathrm{ha}^{-1}$ ) in all intercropping systems were higher than sole maize (9.35 $\mathrm{t} \mathrm{ha}^{-1}$ ) indicating higher productivity of intercropping systems. Similar results were mentioned by Alom et al. (2013). Among 
intercropping systems, maximum MEY (19.39 $\mathrm{t}$ ha ${ }^{-1}$ ) was recorded in maize paired row $(100 \%)+2$ rows squash (100\%) combination. Higher MEY in this combination might be contributed by combined effect of both the components. LER (1.47) also higher in Maize paired row (100\%) + 2 rows squash (Plant to Plant $80 \mathrm{~cm})(100 \%)$ treatment combination indicating 47\% higher land use efficiency. The higher LER might be due to better utilization of growth resources. The results are in agreement with the findings of Seran and Brintha (2009). The highest gross return Tk. 2,93,850 ha-1, gross margin

Tk. 1,92,450 ha ${ }^{-1}$ and BCR 2.95 were obtained from maize paired row (100\%) +2 rows squash (100\%). This result is in agreement with the finding of Islam et al. (2013). Gross margin was higher under intercropping systems than that of sole cropping systems. Many investigators also reported higher gross margin in intercropping system than sole crop (Razzaque et al., 2007 and Alom et al., 2008). The cost of cultivation was much higher under all intercropping systems than sole maize This was mainly due to more expenditure in extra labour required for sowing, harvesting, and intercultural operation of two crops. Monetary advantages were also obtained by Bandyopadhyay (1984) from intercrop combinations of different crops.

Table 3. Maize equivalent yield (MEY), land equivalent ratio (LER) and economic analysis of maize-squash inter cropping systems (Average of two years)

\begin{tabular}{|c|c|c|c|c|c|c|}
\hline Treatments & $\begin{array}{l}\text { Maize } \\
\text { equivalen } \\
\text { t yield } \\
\left(\mathrm{t} \mathrm{ha}^{-1}\right)\end{array}$ & LER & $\begin{array}{c}\text { Gross } \\
\text { return } \\
\left(\mathrm{Tk} \mathrm{ha}^{-1}\right)\end{array}$ & $\begin{array}{l}\text { Cost of } \\
\text { production } \\
\left(\text { Tk ha }^{-1}\right)\end{array}$ & $\begin{array}{c}\text { Gross } \\
\text { margin } \\
\left(\mathrm{Tk} \mathrm{ha}^{-1}\right)\end{array}$ & $\mathrm{BCR}$ \\
\hline $\begin{array}{l}\text { Maize normal planting } \\
(75 \mathrm{~cm} \times 25 \mathrm{~cm})\end{array}$ & 9.35 & 1.00 & 140325 & 69000 & 71325 & 2.03 \\
\hline $\begin{array}{l}\text { Maize normal planting } \\
(100 \%)+1 \text { row squash }(\mathrm{Pl} . \\
\text { to } \mathrm{Pl} .80 \mathrm{~cm})(116 \%)\end{array}$ & 15.89 & 1.26 & 238350 & 99500 & 140350 & 2.39 \\
\hline $\begin{array}{l}\text { Maize paired row }(100 \%) \\
+1 \text { row squash }(\mathrm{Pl} \text {. to } \mathrm{Pl} \text {. } \\
80 \mathrm{~cm})(50 \%)\end{array}$ & 16.13 & 1.33 & 241950 & 82500 & 159450 & 2.93 \\
\hline $\begin{array}{l}\text { Maize paired row }(100 \%) \\
+1 \text { row squash (Pl. to } \mathrm{Pl} \text {. } \\
1 \mathrm{~m})(40 \%)\end{array}$ & 14.97 & 1.29 & 229800 & 79600 & 150200 & 2.89 \\
\hline $\begin{array}{l}\text { Maize paired row }(100 \%) \\
+2 \text { rows squash (Pl. to } \\
\text { Pl. } 80 \mathrm{~cm})(100 \%)\end{array}$ & 19.39 & 1.47 & 290850 & 98400 & 192450 & 2.95 \\
\hline $\begin{array}{l}\text { Maize paired row }(100 \%) \\
+2 \text { rows squash }(80 \%)\end{array}$ & 17.80 & 1.42 & 267000 & 94700 & 172300 & 2.81 \\
\hline Sole Squash $(1 \mathrm{~m} \times 80$ & 17.73 & 1.00 & 266025 & 92000 & 174025 & 2.88 \\
\hline
\end{tabular}

Market price: $\left(\mathrm{Tk} \mathrm{kg}^{-1}\right):$ Maize $=15$, Squash $=10$

\section{Conclusion}

Two years results revealed that squash grown as intercrop with maize is more profitable one than sole maize. So, maize paired row $37.5 \mathrm{~cm} / 150 \mathrm{~cm} / 37.5$ $\mathrm{cm}(100 \%)+2$ rows squash (Plant to Plant $80 \mathrm{~cm})(100 \%)$ combination could be suitable for higher productivity and economic return.

\section{References}


Ahmed, F., M. N. Islam, M. S. Alom, M. A. I. Sarker and M. A. Mannaf. 2013. Study on intercropping leafy vegetables with okra (Abelmoschus esculentus L.). Bangladesh J. Agril. Res. 38(1): 137-143.

Alom, M. S., N. K. Paul, and M. A. Quayyum. 2008. Performance of hybrid maize (Zea mays L.) under intercropping systems with mungbean (Vigna radiata L.) in different planting methods. SAARC J. of Agri. 6(2): 73-82.

Bandyopadhyay, S. N. 1984. Nitrogen and water relations in grain sorghum-legume intercropping systems. Ph. D. Dissertation, Indian Agricultural Research Institute, New Delhi.

Islam, M. N., M. M. Haque and A. Hamid. 2004. Spatial arrangement and population density effects on productivity of maize-bushbean intercropping systems. Bangladesh J. Agril. Res. 29(3): 467-474.

Islam, M. N., M. S. Rahman, F. Ahmed, M. S. Alom and M. Akhteruzzaman. 2013. Performance of different HYV mustard varieties with sugarcane (Sacchaarum officinarum) as intercrop in farmers' fields. Bangladesh J. Agril. Res. 38(1): 137-143.

Lewis, W., Jett, J. S. Chism, S. P. Conley. 2003. Intercropping systems for tomato within a high tunne, Report submitted to Dept.of Horticulture, Missouri Univ.Colombia: 1-18.

Mahfuza, S. N., M. N. Islam, A. Hannan, M. Akhteruzzaman and S. Begum. 2012. Intercropping of different vegetables and spices with pointed gourd. J. Exp. Biosci. 3(1): 77-82.

Razzaque, M. A., S. Rafiquzzaman, M. M. Bazzaz, M. A. Ali, and M. M. R. Talukdar. 2007. Study on the intercropping groundnut with chilli at different plant populations. Bangladesh J. Agril. Res. 32(1): 37-43.

Seran, T. H. and I. Brintha, 2009. Studies on determining a suitable pattern of capsicum (Capsicum annum L.) - vegetable cowpea (Vigna unguiculata L.) intercropping. Karnataka J. Agric. Sci. 22: 1153-1154.

Shivay, Y. S., R. P. Singh and C. S. Pandey. 1999. Response of nitrogen in maize (Zea mays)- based intercropping system. Indian J. Agron. 44: 261-266.

Uddin M. J., M. A. Quayyum and K. M. Salahuddin. 2009. Intercropping of hybrid maize with short duration vegetables at hill valleys of bandarban. Bangladesh J. Agril. Res. 34(1): 51-57.

Willey, R. W. 1985. Evaluation and presentation of intercropping advantages. Exp. Agric. 21(2): 119-133. 